\title{
DESIGN OF THEMATIC INTEGRATIVE LEARNING BASED ON LOCAL ADVANTAGE IN ELEMENTRY SCHOOL
}

\section{Sri Utaminingsih, dan Eka Zuliana}

Universitas Muria Kudus

Email: sri.utaminingsih@umk.ac.id; 吕a.zuliana@umk.ac.id

\section{Info Artikel}

\section{Sejarah Artikel:}

Diterima 27Agustus 2018

Direvisi 17 November 2018

Disetujui 27 November 2018

\section{Keywords:}

Learning Design,Integrated

Theme, Local Advantage

\begin{abstract}
The purpose of this research is to create the integrated thematic learning design based on local advantage in Demak municipality for $3^{\text {rd }}$ grade with traditional game theme. The research design with first step: preparing for the experiment consist of : : (1) literatur study anda FGD with teacher to identify core competences and local advantage, (2) designing the model with scientific approach: (observing, questioning, experimenting, associating, dan communicating), (3) planning for learning implementation, (4) planning for evaluation process by using authentics assesment and (5)Test showed an increase in the quality of the instructional design of learning; (6). FGD with the expert to discuss early design so that can be get valid design. The result of this research can be get the design of model: integrated thematic learning based on local advantage in Demak municipalitythat can improve the quality of learning of elementary school students
\end{abstract}

\begin{abstract}
Abstrak
Tujuan penelitian ini adalah untuk menciptakan desain pembelajaran tematik terpadu berbasis keunggulan lokal di kota Demak untuk kelas 3 dengan tema permainan tradisional. Rancangan penelitian dengan langkah pertama: persiapan untuk percobaan terdiri dari: (1) studi literatur dan FGD dengan guru untuk mengidentifikasi kompetensi inti dan keunggulan lokal, (2) merancang model dengan pendekatan ilmiah: (mengamati, mempertanyakan, bereksperimen, mengasosiasikan , dan berkomunikasi), (3) perencanaan untuk pelaksanaan pembelajaran, (4) perencanaan untuk proses evaluasi dengan menggunakan penilaian otentik dan (5) Tes menunjukkan peningkatan kualitas desain pembelajaran instruksional; (6). FGD dengan ahli untuk mendiskusikan desain awal sehingga bisa mendapatkan desain yang valid. Hasil penelitian ini dapat memperoleh desain model: pembelajaran tematik terpadu berbasis keunggulan lokal di kota Demak yang dapat meningkatkan kualitas pembelajaran siswa sekolah dasar.
\end{abstract}

(C) 2018 Universitas Muria Kudus 
Utamingsih, Sri., dan Zuliana, Eka

DESIGN OF THEMATIC INTEGRATIVE LEARNING BASED ON LOCAL ADVANTAGE ...

REFLEKSI EDUKATIKA : Jurnal Ilmiah Kependidikan, Nomor 9, Volume 1, Desember 2018, hlm.

\section{BACKGROUND}

Reflect the results of TIMSS or PISA student learning achievements as a parameter on the international scale, we need to examine again how the practice of learning that is now happening. The achievements of our students still in concern, according to the TIMSS 2011 in the rank of 38 from 42 countries while in PISA 2009 from 65 countries Indonesia on the ranking of 57 to 61 for reading, math and 60 for science. Most of the our students only able to work on the problem up to middle level only, and from these results look that education in Indonesia so far too focused on the technical proficiency and unable to come to the thinking process. This requires us to look at the learning practices in countries that succeed in education. Widdiharto (2013) mention some countries that succeeded in his studies applying the pattern of scientific approach (i.e.: observe, ask yourself, thinking, and networking/concluded) in the learning process for their students. The paradigm of constructivism, collaborative learning, as well as authentics assessment become pillars of education in child feeding their people.

The challenges of the $21 \mathrm{st}$ century demands the students more productive, creative, innovative, and affective through the strengthening of attitudes (know why), skills (know how), and knowledge (know what) that integrates (Kemdikbud, 2012). As such, the Government has issued several policies to support successful utilization of demographic bonus: with the release of the curriculum of 2013. Curriculum 2013 development, is to giving the answers to some of the problems inherent to in curriculum 2006, also has aims to encourage the students, capable of doing better in the observation, questioning, thi, and king; communication (presenting), what they know after students receive learning material. (Kemdikbud, 2012). On the level of SD/MI will get a portion of the changes quite a lot. One feature of the curriculum by 2013 thematic is integrative. The curriculum 2006 (KTSP) already mandated thematic learning for the class I - III SD. However, in practice, there are still many teachers and schools that have not yet to implement. Patterns of teacher centered still dominates in Elementary learning especially in Demak. The Patterns of teacher centered affected to the students in the construction of knowledge, students are less fixated on the cognitive aspect of the course, where the students are not be given the opportunity to explore his ability in explorating the potential of the local advantage of Demak in which is supposed to be able to serve as learning resources in the thematic learning is also insufficient. Elementary students old, at the age between $7-13$ years. According to Piaget, they are on concrete operational phase (Ibrahim Suparni, 2012:79). Based on this phase, learning should be prefaced with something real close to life, knowledge and experience of students. Construction of knowledge would be easier if departing from real experience close to students, related to reality, it's easy to imagine (imagineable), takes the form of an activity and habits that are often done in the environment or the surrounding area.

Departing from this problem, needed a valid learning model in supporting the learning process in SD Demak in order to provide a climate conducive for the development of power of thinking, increase activity, creativity of students as well as instilling a love of potential local excellence of Demak. Thematic learningbased integrative based on local advantage is a learning approach integrates the various competencies of the various subjects into themes, in practice the potential and advantages of Demak lokal can be used as a source of learning.

Based on the background of the issued above, the author would like to design thematic learning-based integrative local superiority of Demak. Nurjhani, et al (2003) stated that by implementing a model of thematic learning, learning more effective and able to develop the ability to work scientifically in elementary school. In addition Suryanti (2008) stated the results of the tests of the wide scale (3 elementary school) in the city of Surabaya showed that there is the influence of the application of learning materials (learning device) against the results of the thematic Learning students.

The purpose of this research were: 1) Makes the design prototype and produce thematic integrative learning design in elementary schoolbased local advantages of Demak; 2). implementing the thematic integrative in elementary school using the prototype model of thematic learning-based local advantages of Demak; 3). Analyzing the effectivity of implementation of thematic learning model of integrative medicine in elementary school -based local advantages of Demak. On this article are limited in making the design prototype and produce thematic 
integrative learning design in Elementary School based local advantages of Demak.

\section{RESEARCH METHODS}

The research methods is using the method and design research. The steps of Research design as well as on the process of design education (educational design), namely analysis, design, implementation and revision is the process of cyclical creation raises that ended in a balance between ideal theories with practice. According to Gravemeijer Cobb (2006) phase of design research is: 1) preparing for the experiment (preparation study), 2) design experiment (implementation of the experimental design), and 3) retrospective analysis (analysis of data obtained from the previous phase).

In this article the first stage delivered : is Preparing For The Experiment. The collection of data in this study use techniques: (1) in-depth interviews; (2) observation; (3) Focus Group Discussion; and (4) the study documentation. It also used the tests to collect data on the value of student learning outcomes after getting a thematic-based integrative learning based on Local Advantage of Demak. Question form is used to collect the data response students and teachers towards learning thematic-based local advantages of Demak. Data analysis using descriptive analysis techniques which according to Miles and Huberman (1984) performed through three interrelated activities with each other, namely: (1) reduction of data (data reduction); (2) the exposure data (data display); and (3) the withdrawal of the conclusion.

\section{FINDING AND DISCUSSION}

The Process Research of Restyling Thematic Integrative Learning Models based on local Advantage on Demak beginning with: 1). The study of the literature and discussion with the teacher to determine local advantages which can be used in the learning process. Some local advantage Demak who can become learning resources in the thematic learning include: a) the pomegranate Guava and Starfruit. Demak; b). Rice, green beans and corn; c). The great Demak
Mosque; d) pilgrimage to the tombs of sultans of Demak Sunan Kalijaga; e). The people's night market at Tembiring Jogo beautiful; f) celebrate the Tumpeng Sanga and the sharing of meals; $g$ ). Slolat Ied; h). The great Giant Culture; I). Penjamasan Heritage relics of Sunan Kalijaga.

Every 10th of Dzulhijah Muslims commemorate the feast of Eid al-Adha Prayers by implementing and continued with the slaughtering of the animal sacrifices. At the time of wali sanga, in an environment of Masjid Agung Demak assimilated with religious rituals, as an attempt by the Islamic Messenger Wali Sanga. This activity is called a giant Great Demak. To date these activities still take place, even developed. j). The art of zippin, a famous town of Demak guardian very closely with arts and religious cultural. One of them is art zippin. This art is usually played at a time when Islamic holidays, weddings, circumcision, or other major events. This art is played with a set of musical instrument consisting of a drum, tambourine, ketipung, as well as jidur. The art contains the stories of the prophets, the guardian, as well as Islamic songs. k). Traditional games such as: Kites, Dakon, Stilts, Engklek, Betengan, Bekelan, Marbles, jump rope, etc. Some of the benefits of the child play, especially the game engklek: 1) Game Engklek Geometry can enhance children's cognitive ability and liveliness; 2). the child can improve motor ability elements, namely, speed, strength, coordination, balance and agility; 3) Sharpening the ability to socialize with others and teach the togetherness; 4. develop a logic of intelligence). Engklek game train for counting and determining the steps that should be was spent;5.) Children to be more creative. Traditional games are usually made directly by the players. They use the goods, objects, or existing plants around the players. It encouraged them to create more creative tools game.; 6). Train your balance. This traditional game using one foot to jump from the satukotak to the next; 7) motor skills to train children's hand because in this game children throw the gacuk must be/kreweng. (Mujiati 2012; Apriani, 2013; Darmayeti; 2012). 
Utamingsih, Sri., dan Zuliana, Eka

DESIGN OF THEMATIC INTEGRATIVE LEARNING BASED ON LOCAL ADVANTAGE ...

REFLEKSI EDUKATIKA : Jurnal Ilmiah Kependidikan, Nomor 9, Volume 1, Desember 2018, hlm.

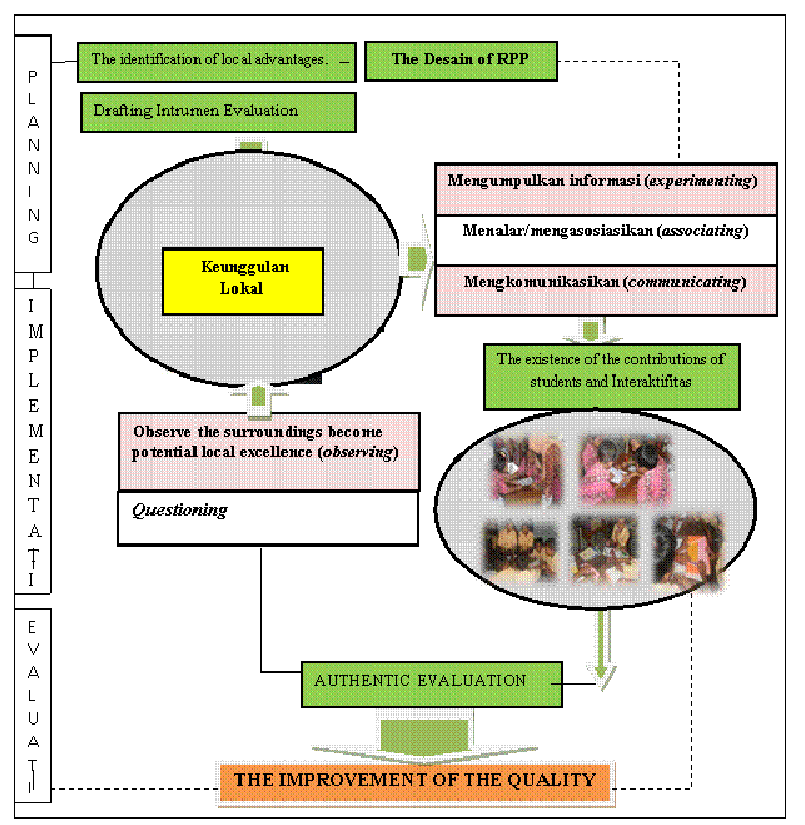

Figure 2. Design-Based Learning, Excellence Local Demak

As for the scientific approach in Thematic Learning Model-based Integrative Local Advantages are: 1) Observing; Students perform observations on the potential advantages of local regions. 2). Questioning; The question of granting fishing and leads to the concept of themes studied. 3) Experimenting; Students conduct an experiment/try to use the potential of local advantages which are already observed to build new concepts according to the theme; Associating; 4). Students in the process of bernalar and discussions with friends and teachers to cultivate and build the concept. 5). Communicating; Students communicate the idea to the teachers and friends-her friend to another.

\section{Plan implementation process of learning with a Model Thematic Learning-based Integrative Local superiority of Demak.}

Beginning with analyzing and identifying competencies Theme traditional games. Indonesian Language competence: 1) Identify information game instructions jiggle Tin; 2) Practicing traditional game about the life of animals and plants fit the text instructions. Mathematics: 1) Identifies the results of the reflection of a flat wake; 2) attest to the results of a reflection object. SBdP; 1). Understanding how to plant vegetable crops in the surrounding environment. 2). Practice grow vegetables on surrounding environment
The Learning Steps I. : 1) Teacher invites students to the field School Students listen to explanation; 2) teachers regarding game jiggle Tin (tongmuk in Javanese); 3) Representatives of the student group demonstrated the game tong muk, another group watched a demonstration of the game (Observed); 4) Students requested recounts orally about uruan game tong muk correctly (Thinking); 5) Students singing the song "planting corn" together; 6) The students identify the steps of planting corn based on songs that are sung (Thinking); 7) Students in a group went to the garden of the school which became the location of the plant the corn; 8) The teacher explains the introduction about planting corn.; 9) Students gather to plant equipment that has been assigned in groups; 10) Student name menampelkan in a pot/polybag/cans brought; 11). Each student prepare equipment to harvest them, and the practice of planting green beans, corn, rice, in the guidance teachers (try); 12) One student recounted their experiences when planting, other students listen and give feedback about the sequence of the plant delivered his friend (communicate),;13). The teacher game conveys about the magic mirror, where students will pair up and do a suit. The winning students will demonstrate some of the styles are sholah reflect, students who lost should be able to demonstrate the style exactly as if he is a shadow in the mirror, it is done repeatedly. In turn the shadows doing wrong or too late do the 
movement, then his face crossed out with powder (observing and trying); 14) Any student looking for a friend to play magic mirror; 15) The teacher explains that when playing the right things, it will be seen as the left direction of the shadow. But the size and color of objects will be exactly the same as the object; 16). Students working on the problem in the book the student regarding the reflection of the wake. (try and menalar); 17) After working on the book in question exercises, teachers and students are discussing the along with the correct answers. (communicate); 18). Teachers and students learning about concluded visualizing wake up.

\section{Steps of Learning II}

1) Students see teachers held kelerang and mention the information they know about the object (observe); 2) Students listen to the teacher's explanation about the game of marbles, the teacher tells the popularity of marbles in the past; 3) Students read the text contained in the student's book, and answer the questions contained in the book with a latin inscription connect correctly (try and thinking); 4). Students doing a simple warming movements such as stretching of the muscles of the hands and feet (try); 5) The teacher explains the kind of movement that will be done in the game of marbles relay is twisting, squatting and continuous improvement. Teachers exemplify the right technique; 6) Students doing games relay game according to the instructions contained in this book (try); 7) The teacher gives appreciation to a group of students who win the race; 8). Students in turn mentions the benefits of relay game marbles; 9) Students and teachers discuss the exercise problem together, and make a conclusion about the information contained in the text; 10) Students gathered in the field and repeat the previous lesson go back on motion of non locomotor.

\section{Plan The Evaluation Process With Uuthentic Assessment.}

Evaluation used in the study used the concept of authentic just my assesment (actual assessment). Authentic assessment - an assessment which is used, among others: a).based assessment project; b). Assessment of products; c). Assessment of performen (performance).

\section{Limited Trial of Design}

Do a thematic study integrative class III with the theme of the game, learning Traditional I and II. Observations on the early trial of teacher quality obtained a score of 85 with a percentage of $67,11 \%$, qualifying well. Learning activities of students ' affective domain obtained percentage of $65.02 \%$ and activity of students acquiring percentage of psychomotor domain $66,21 \%$. . The observations showed an increase in the quality of the material. The improvement of the quality of the material with proven data observations obtained the percentage of $82,75 \%$. Media quality observations and climate learning alike earn a percentage of $83,33 \%$.

\section{Expert Examination Against Initial Design So Obtained A Valid Design}

Based on experts who reviewed the design of Thematic Learning-based Integrative model based on local advantage Demak obtained valid results with little revision. As for those revisions include: a) the identification of local excellence involves students b) establishment of the understanding of the subjects on the theme/sub theme by optimise learning resource from a local c) Excellence In the learning process, scientific activities needs to be further clarified d) contribution of teachers and students made clear in the implementation of thematicbased integrative learning based on local advantage of Demak as for picture improvement instructional design Excellence-based Integrative Local Thematic Demak after revised is as follow 


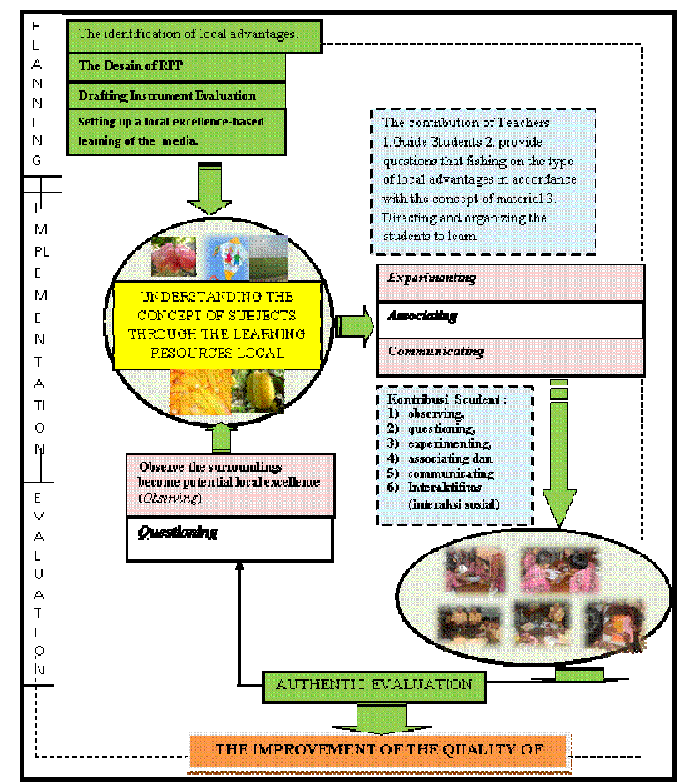

Figure 4. Thematic Learning Model Of Integrative Design-Based Local Advantages Of Demak And To Improve The Quality Of Learning. (Revised)

\section{CONCLUSION}

Retrieved design models of integrative learning thematic-based local advantages, namely Demak consists: planning, include: Identified local advantage, preparation of the RPP, Formulating Instrument Evaluation, prepare a medium of instruction. based local advantages. Implementation includes the following: observe and Ask about local excellence of Demak which can be used as a learning resource to enhance the understanding of the concept, try, menalar, communicate with the increasing contribution of teachers and interactivity students, as well as doing the evaluation of the authentic. The results of the initial test of the quality of the learning that judging from the quality of teacher, student activities, materials, media and learning climate in qualification either.

Advice on local advantages Should be dug deeper and utilized for the learning process, in addition to understanding material, the insertion of local advantages in the learning process is also able to help raise the next generation against the love for the motherland. Credits Department of Central Java province which has provided an opportunity to the author to do the research and contributed ideas in order to improve the quality of primary school graduates

\section{REFERENCES}

Asmani, J. 2012. Pendidikan Berbasis Keunggulan Lokal. Yogyakarta : DIVA Press.

Apriani, 2013. . "Penerapan Permainan Tradisional Engklek untuk Meningkatkan Kemampuan Motorik Kasar". Surabaya: 2013, tersedia di http://ejournal.unesa.ac.id

Darmayeti. 2012. "Peningkatan Kemampuan Motorik Kasar melalui Permainan Engklek pada Anak Usia 5 - 6. Tersedia di: http://jurnal.untan.ac.id/index.php/ipdpb/art icle/download/4601/4685.

Depdiknas. 2006. Strategi Pembelajaran yang Mengaktifkan Siswa. Jakarta : Depdiknas.

Gravemeijer \& Cobb. 2006. "Design Research from a Learning Perspective, dalam Educational Design Research. New York : Routledge.

Hidayat, M. 2005. Teori Pembelajaran Matematika. Semarang: PPs UNNES.

Ibrahim \& Suparni. 2012. Pembelajaran Matematika Teori dan Aplikasinya. 
Utamingsih, Sri., dan Zuliana, Eka

DESIGN OF THEMATIC INTEGRATIVE LEARNING BASED ON LOCAL ADVANTAGE ...

REFLEKSI EDUKATIKA : Jurnal Ilmiah Kependidikan, Nomor 9, Volume 1, Desember 2018, hlm.

Yogyakarta: SUKA-Press UIN Sunan Kalijaga.

Kemdikbud. 2012. Pergeseran Paradigma Belajar Abad 21. Artikel dimuat dalam www.kemdikbud.go.id. Diunduh 8 Juni 2013.

Kemdikbud. 2012. Tidak Menghapus Mata Pelajaran. Artikel dimuat dalam www.kemdikbud.go.id. Diunduh 8 Juni 2013.

Kemdikbud. 2012. Struktur Kurikulum 2013. Artikel dimuat dalam www.kemdikbud.go.id. Diunduh 8 Juni 2013.

Mujiati, 2012. "Penerapan Permainan Engklek Geometri untuk meningkatkan keaktifan dan kemampuan kognitif anak kelompok $A$ di RA Qomarul Hidayah Tambaksari Purwodadi Pasuruan". Malang: Skripsi.

Milles, M.B, \& huberman, A.M, 1984; Analisis Data Kualitatif; Terjemahan oleh Tjetjep Rohidi dan Mulyarto, Jakarta; Indonesia Press.

Nurjhani, Mimin., dkk. 2003. Model Pembelajaran Tematik 'Makanan Untuk Hidup' Dengan Mengembangkan Kemampuan Bekerja Ilmiah Di Sekolah Dasar. Jurnal Penelitian Pendidikan, 3(3).

PISA 2009 Results: What Students Know and Can Do. Student Performance in Reading,
Mathematics and Science (Vol.1). Paris: OECD.

Pratiwi dan Mulyani. 2013. Penerapan Media Papan Balik (Flipchart) pada Pembelajaran Tematik untuk meningkatkan Hasil Belajar Siswa Sekolah Dasar. Jurnal Penelitian Pendidikan Guru Sekolah Dasar. 1(2), hal: $1-10$.

Saptaningrum dan Kusdaryani. 2010. Model Pakem Melalui Pendekatan Tematik Untuk Pembelajaran Sains SD. Jurnal Penelitian Pembelajaran Fisika, 1(1), hal: 92 - 104.

Suryanti. 2008. Pengembangan Perangkat Pembelajaran Tematik untuk Meningkatkan Kualitas Pembelajaran di Kelas Rendah Sekolah Dasar. Jurnal Pendidikan Sekolah Dasar, 5(3).

Utaminingsih, Sri, 2014. Improving The Quality Of Thematic Scientific Learning Based On Soft Skill Through Lesson Study In Elementary School. Artikel Seminar Internasional, UPI, Bandung.

Trianto. 2010. Mengembangkan Model Pembelajaran Tematik. Jakarta : Prestasi Pustaka Karya.

Widdiharto, R. 2013. Perubahan Kurikulum dan Tugas Guru. Artikel Pendidikan dimuat dalam www.p4tkmatematika.org. Diunduh 8 Juni 2013. www.demakkab.go.id 